\title{
ANALISIS KONSEP BISYARAH PADA JAMAHER NETWORK DALAM PRESPEKTIF EKONOMI ISLAM
}

\author{
Oleh: \\ Abdur Rohman
}

\section{Abtrak}

Jika kita menengok tentang perkembangan Multi Level Marketing di Indonesia, bisa disimpulkan karena tidak lepas dari pengaruh makin berkembangnya dunia online. Perusahaan dengan landasan Multi Level Marketing (MLM) dimana dulu hanya bergerak secara offline, sekarang sudah mulai merambah untuk memasarkan secara online. Bahkan pencatatan member yang dulu dilakukan secara manual sekarang sudah beralih serba otomatis yang dikerjakan dengan sistem mesin. Sedangkan kegiatan MLM offline hanya sebatas seminar-seminar atau iklan melalui media cetak. Banyak keuntungan yang didapat sebuah perusahaan MLM dengan menggunakan sistem online. Dengan adanya sistem online member dapat mengakses dari manapun, dan juga member yang bergabung tidak hanya berasal dari perusahaan MLM itu berada. Tetapi member dari berbagai daerah juga dapat bergabung disini. Antara member upline dan downline juga belum tentu pernah bertatap muka. Jika kita menyimak hal tersebut bisa dikatakan jika perkembangan Multi Level Marketing di Indonesia makin berkembang secara pesat di iringi dengan kemajuan teknologi. Salah satunya adalah MLM jamaher, pihak ini menyebut bahwa selain MLM (Multi Level Marketing juga bermakna Multi Level Muamalah. Oleh karena peneltian ini menarik untuk dikaji lebih dalam terkait dengan sytem plan atau marketing www.jamaher.network dalam prespektif ekonomi Islam.

* Ketua Pusat Ekonomi Islam Universitas Trunojjoyo MaduraEmail: rohman09-utm.gmail.com / amans_07@yahoo.co.id 
Kata Kunci : Konsep Bisyarah, Jamaher Nerwork, Perspektif Ekonomi Islam

\section{Pendahuluan}

Ajaran Islam yang syumul bervisi rahmatan lil alamin, tidak hanya mengatur hubungan antara manusia dengan pencipta-Nya (hablum minallah), melainkan hubungan antara manusia dan sesamanya (hablum min al-nas) ${ }^{1}$. Kedua hal tersebut tidak dapat dipisahkan. Terlebih dalam hal menjalankan tugasnya sebagai khalifah untuk memakmurkan bumi, suatu tugas yang tidak dapat diemban oleh semua makhluk meskipun malaikat sebagai hamba Allah SWT yang taat menjalankan perintah-Nya.

Beberapa firman-Nya dalam Al Qur'an, Allah SWT. memerintahkan kepada manusia untuk bekerja dan berusaha memenuhi kebutuhan hidup sehari-hari, dari pekerjaan yang ringan sampai pada pekerjaan yang berat. Semuanya dilakukan hanya untuk memenuhi kebutuhan hidup. Seperti dalam Q.S. Al Jumuah: 11

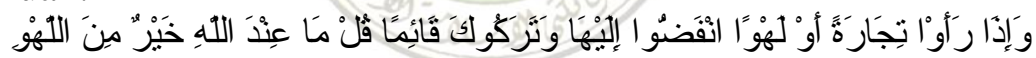

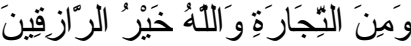

Terjemahnya :"Dan apabila mereka melihat perniagaan atau permainan, mereka bubar untuk menuju kepadanya dan mereka tinggalkan kamu sedang berdiri (berkhutbah). Katakanlah: "Apa yang di sisi Allah adalah lebih baik daripada permainan dan perniagaan", dan Allah Sebaikbaik Pemberi rezeki".

Berbagai inovasi pelaku dunia usaha terutama perdagangan dalam upaya untuk menciptakan srrategi yang tepat untuk membidik konsumen. Strategi pemasaran yang menjadi kunci pokok keberhasilan dalam perkembangan produk untuk

${ }^{1}$ Amir Syarifuddin, “Garis-Garis Besar Fiqih". Cet ke-3 ( Jakarta: Pranada Media Group, 2010 ), hlm. 175.

${ }^{2}$ Departemen Agama RI. Al-Qur'an dan Terjemahannya, (Semarang: Toha Putra, 1971), hlm. 552 
sampai pada konsumen terus berusaha mengembangkan pemasaran yang awalnya hanya dapat menawarkan barang atau jasa.

Dunia semakin maju, teknologi semakin canggih dan sistem perdagangan pun semakin banyak, semarak dan beraneka ragam. Kaum kafir memang masih menguasai ekonomi, bisnis dan perdagangan dunia. Umat Islam masih jauh ketinggalan, bahkan nampak semakin tercekik, tidak bisa banyak berbuat, apalagi mengamalkan dan mempraktikkan hukum-hukum Islam.

Sejak beberapa tahun ini, muamalah MLM (Multi Level Marketing) semakin marak dan banyak diminati orang, lantaran perdagangan dan muamalah dengan sistem MLM ini menjanjikan kekayaan yang melimpah tanpa banyak modal dan tidak begitu ruwet. Betulkah yang mereka harapkan itu terjadi? Jaringannya tersebar di seluruh dunia, tidak terkecuali negara tercinta kita Indonesia.

Multi level marketing adalah jalur alternatif bagi suatu perusahaan, dengan model MLM merupakan salah satu cara pemasaran untuk menjual barang secara langsung (direct selling). Direct selling sendiri, pengertiannya adalah penjualan barang dan atau jasa tertentu kepada konsumen dengan cara tatap muka dalam jaringan pemasaran yang dikembangkan oleh Mitra Usaha dan bekerja berdasarkan komisi penjualan, bonus penjualan dan iuran keanggotaan yang wajar.

Di Indonesia, istilah MLM dikenal pada awal tahun 1980an. Dan pada tahun 1984 terdapat Asosisasi Penjualan Langsung Indonesia (APLI) yang menjadi suatu organisasi yang merupakan wadah persatuan dan kesatuan tempat berhimpun para perusahaan penjualan langsung, termasuk perusahaan yang menjalankan penjualan dengan system berjenjang (Multi Level Marketing) di Indonesia.

MLM sendiri masuk kategori dalam bab Muamalat, yang mana pada dasarnya berhukum mubah atau boleh. Hal tersebut merujuk kepada kaidah yaitu:
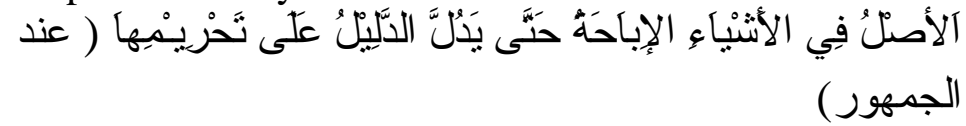
Artinya : Bahwa hukum segala sesuatu itu pada asalnya adalah boleh. Sampai nanti ada hal-hal yang ternyata dilarang atau diharamkan dalam syariah Islam.

Dalam perkembangannya ada MLM yang membuat istilah berbeda dengan MLM-MLM sebelumnya, yaitu Jamaher.network. MLM dalam pandangan ini adalah Multi Level Muamalah yang baru berdiri bulan September 2016. Sehingga menarik untuk ditindak lanjuti dalam sebuah penelitian, khususna pada system plan atau marketing plannya dalam prespektif ekonomi Islam.

\section{Dalil dan Metode Memahami Dalil Hukum Bisnis MLM}

Semua bisnis termasuk yang menggunakan sistem MLM dalam literatur syari'ah Islam pada dasarnya termasuk kategori mu'amalat yang dibahas dalam bab Al-Buyu' (Jual-beli) yang hukum asalnya dari aspek hukum jual-belinya secara prinsip boleh berdasarkan kaidah Fiqih sebagaimana dikemukakan oleh Ibnul Qayyim Al-Jauziyah. Bisnis dalam syari'at Islam pada dasarnya termasuk dalam kategori muamalah yang hukum asalnya adalah boleh.

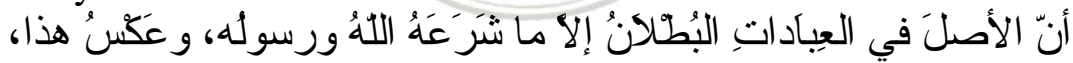

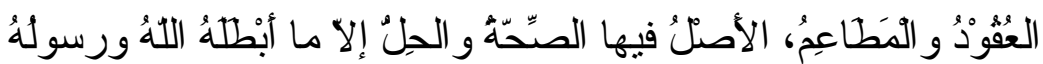

Artinya: "Pada dasarnya semua ibadah hukumnya bathil (haram), kecuali apa yang disyari'atkan oleh Allah dan Rasul-Nya. Dan sebaliknya, dalam semua transaksi ('aqad, muamalah) dan makanan pada dasarnya sah dan halal, kecuali apa yang diharamkan oleh Allah dan Rasul-Nya".

Berdasarkan kaedah fiqih di atas, terlihat jelas bahwa dalam wilayah muamalah, Islam memberikan jalan bagi manusia untuk melakukan berbagai improvisasi dan inovasi melalui sistem, teknik dan mediasi dalam melakukan perdagangan atau bisnis lainnya. Selama muamalah itu tidak melanggar prinsip-prinsip syari'ah, maka hukumnya diperbolehkan. 
Namun syari'at mempunyai prinsip-prinsip yang harus dipenuhi dalam pengembangan sistem sebuah bisnis, agar dalam usaha menghasilkan keuntungan tidak dilakukan secara batil. Dalam firman-Nya ditegaskan :

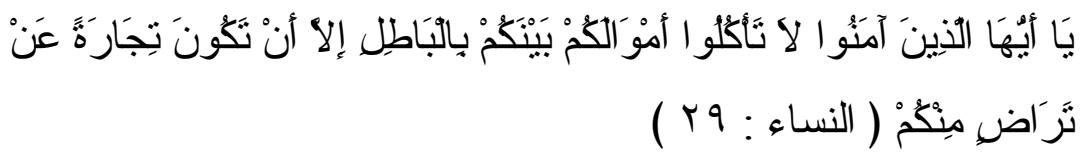

Terjemahnya: "Hai orang-orang yang beriman, janganlah kamu saling memakan harta sesamamu dengan jalan yang batil, kecuali dengan jalan perniagaan yang berlaku dengan suka sama-suka di antara kamu".3

Ada beberapa hal prinsip yang harus dihindari dalam sebuah bisnis, Ibn Rusyd dalam kitab Bidāyah al-Mujtahid mengatakan :

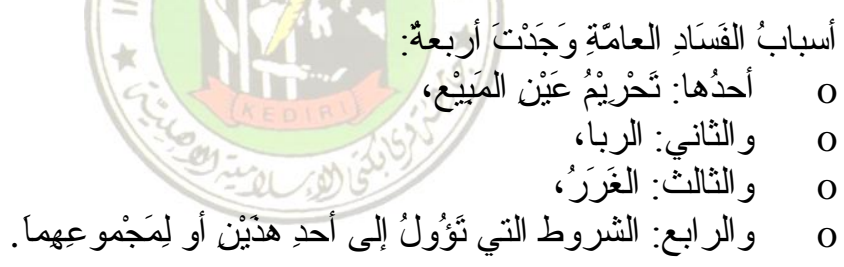

Artinya: "Sebab-sebab umum rusaknya (bisnis) ada empat: Pertama, benda yang diperjual-belikan haram. Kedua, riba. Ketiga, gharar (penipuan). Dan keempat, terdapat unsur-unsur yang dapat mengarah kepada salah satu dari keduanya (riba dan gharar) atau keduanya sekaligus".

Keempat hal di atas merupakan hal-hal pokok yang dapat menjadikan sebuah bisnis menjadi haram dari dalam 'aqad bisnis itu sendiri. Adapun hal di luar 'aqad yang menyebabkan terlarangnya bisnis antara lain: al-ghasy (penipuan, pemalsuan), al-dlarar (membahayakan), waktu terlarang untuk bertransaksi, dan kriteria pelaku yang tidak diperbolehkan melakukan transaksi. Sebuah bisnis atau usaha apapun juga menjadi haram jika dilakukan atas dasar spekulasi yang tinggi atau adu nasib,

\section{${ }^{3}$ QS. An-Nisa': 29}


karena hal ini tergolong perjudian (maysir) yang jelas-jelas dilarang dalam firman Allah dalam surat Al-Maidah ayat 95:

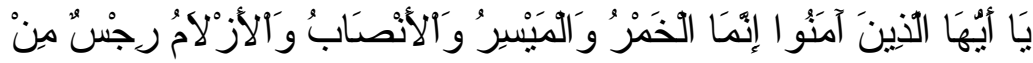

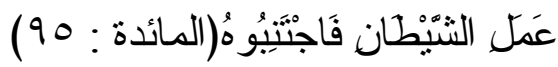

Terjemahnya: "Hai orang-orang yang beriman, sesungguhnya (meminum) khamar, berjudi, (berkorban untuk) berhala, mengundi nasib dengan panah, adalah perbuatan keji termasuk perbuatan syaitan. Maka jauhilah perbuatan-perbuatan itu"4

Ibn Sîrîn memberikan batasan maysir sebagai berikut :

Artinya: "Segala hal yang di dalamnya terdapat khathar (taruhan, spekulasi tinggi yang menyebabkan kecemasan) adalah termasuk maysir"

Semua bisnis yang menggunakan system MLM dalam literature fiqih termasuk dalam kategori muamalah yang dibahas dalam bab Al-buyu' (Jual Beli).

Dalam kajian Fiqih kontemporer bisnis MLM ini dapat ditinjau dari dua aspek yaitu produk barang atau jasa yang dijual dan cara atau system penjualannya (selling marketing). Mengenai produk atau barang yang dijual apakah halal atau haram tergantung kandungannya, apakah terdapat sesuatu yang diharamkan Allah seperti: unsure babi, khamr, bangkai atau darah. Begitu pula dengan jasa yang dijual apakah mengandung unsure kemaksiatan seperti praktik perzinaan, perjudian atau perdagangan anak dsb, dan ini semua bisa kita rujuk pada sertifikasi Halal dari LP-POM MUI. ${ }^{5}$ https://draft.blogger.com/blogger.g?blog|D=235288467181201 8600 - _ftn8

\section{${ }^{4}$ QS. Al-Māidah: 90}

${ }^{5}$ Fatwa DSN MUI Praktek Perbankan Syariah dalam http://pengusahamuslim.com/fatwa-dsn-mui-145 Diakses pada tanggal 27 Maret 2016 
Perusahaan yang menjalankan bisnisnya dengan system MLM tidak hanya sekedar menjalankan penjualan produk barang, melainkan juga produk jasa, yaitu jasa marketing yang berlevel-level (bertingkat-tingkat) dengan imbalan berupa marketing fee, bonus sebagainya tergantung level, prestasi penjualan dan status keanggotaan distributor. Jasa penjualan ini (makelar) dalam terminology Fiqih disebut sebagai "Samsarah/Simsar". Maksudnya perantara perdagangan (orang yang menjualkan barang atau mencarikan pembeli) untuk memudahkan jual beli.

Pekerjaan Samsarah/Simsar yang berupa makelar, distributor atau agen dalam Fiqih termasuk akad Ijaroh yaitu transaksi memanfaatkan jasa orang dengan imbalan.

Pada dasarnya para ulama seperti Ibnu Abbas, Imam Bukhori, Ibnu Sirin, Atha dan Ibrahim memandang boleh jasa ini. Namun untuk sahnya pekerjaan ini harus memenuhi beberapa syarat diantaranya:

1. Adanya perjanjian yang jelas antara kedua belah pihak.

2. Objek akad bisa diketahui manfaatnya secara nyata dan dapat diserahkan

3. Objek akad bukan hal-hal yang diharamkan dan maksiat.

Distributor dan perusahaan harus jujur, ikhlas, transparan, tidak menipu dan tidak menjalankan bisnis yang haram dan syubhat (tidak jelas halal/haramnya). Distributor dalam hal ini berhak menerima imbalan setelah berhasil memenuhi akadnya. Sedangkan pihak perusahaan yang menggunakan jasa marketing harus segera memberikan imbalan para distributor dan tidak boleh menghanguskan atau menghilangkannya. Pola ini sejalan dengan surat Al-Baqarah : 233

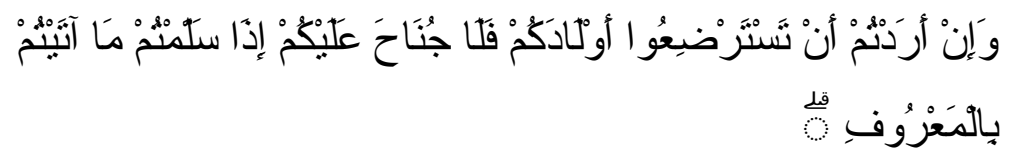


Terjemahnya: "Dan jika kamu ingin anakmu disusukan oleh orang lain, Maka tidak ada dosa bagimu apabila kamu memberikan pembayaran menurut yang patut... ${ }^{6}$.

Jadi pada dasarnya hukum dari MLM ini adalah mubah berdasarkan kaidah Ushuliyah "Al-Ashlu fil mu'amalah alibahah hatta dallad dalilu ala tahrimiha (asal dari semua transaksi / perikatan adalah boleh sehingga ada indikator yang menunjukkan keharamannya). Selain itu bisnis ini bebas dari unsur-unsur Riba (sistem bunga), gharar (penipuan), dharar (bahaya), jahalah (tidak transparan) dan zhulm (merugikan orang lain) dan yang lebih urgen adalah produk yang dibisniskan adalah halal. Karena bisnis MLM merupakan bagian dari perdagangan oleh sebab itu bisnis ini juga harus memenuhi syarat dan rukun sahnya sebuah perikatan.

Secara realita, kini perusahaan MLM sudah banyak tumbuh dan berkembang baik di dalam maupun luar negeri. Bahkan di Indonesia sudah ada yang secara terang-terangan menyatakan bahwa MLM tersebut sesuai syariat dan mendapatkan sertifikasi halal dari Dewan Syariah Nasional Majelis Ulama Indonesia (DSN-MUI). Untuk MLM yang berdasarkan prinsip syariah ini, masih diperlukan akuntabilitas dari MUI.

Ada dua aspek untuk menilai apakah bisnis MLM itu sesuai dengan syariah atau tidak yaitu:

1. Aspek produk atau jasa yang dijual

2. Sistem dari MLM itu sendiri ${ }^{7}$

Dari aspek produk yang dijual, dalam hal ini objek dari MLM harus merupakan produk-produk yang halal dan jelas bukan produk yang dilarang oleh agama. Selain halal objek yang dijual juga harus bermanfaat dan dapat diserahterimakan serta mempunyai harga yang jelas. Oleh karena itu walaupun MLM dikelola atau memiliki jaringan distribusi yang dijalankan oleh

${ }^{6}$ Q.S Al-Baqarah : 233

${ }^{7}$ Dewan Syariah dalam MLM diambil dari http://www e-syariah.com Diakses pada tanggal 27 Maret 2016 
orang muslim namun apabila objeknya tidak jelas bentuk, harga dan manfaatnya maka hal itu bisa dikatakan tidak sah.

Adapun dari sudut sistem MLM itu sendiri, sistem distribusi pendapatan haruslah dilakukan secara professional dan seimbang. Dengan kata lain tidak terjadi eksploitasi antar sesama. Sedangkan dalam menetapkan harga kalaupun keuntungan (komisi dan bonus) yang akan diberikan kepada para anggota berasal dari keuntungan penjualan barang bukan berarti harga barang yang dipasarkan harus tinggi. Hendaknya semakin besar jumlah anggota distributor maka tingkat harga makin menurun yang pada akhirnya kaum muslimin dapat merasakan system pemasaran tersebut.

Seperti yang sudah disingguh di atas, bahwa bisnis Multi Level Marketing merupakan masalah muamalah dalam perspektif fiqih. Dan setelah diamati ternyata pada bisnis multi level marketing yang dipakai oleh perusahaan-perusahaan terdapat dua masalah fiqih yang menganjal bisnis MLM, yakni;

1. Makelar di atas Makelar

Pada dasarnya, aqad samsarah (makelaran) adalah aqad yang melibatkan seorang makelar dengan pemilik barang (shahib al-mâl); atau pembeli barang. Jika pemilik barang meminta seseorang untuk menjualkan barangnya dengan komisi tertentu, maka ini adalah makelaran yang sah. Demikian pula jika seorang pembeli barang meminta seseorang untuk mencarikan barang tertentu dengan komisi tertentu, maka makelaran seperti ini juga absah menurut syara'

Muhammad bin Abi al-Fath, Ulama' penganut Hambali, dalam kitabnya, al-Mutalli, ${ }^{8}$ telah meyatakan definisi tentang pemakelaran, sebagai berikut:

"Jika (seseorang) menunjukkan dalam transaksi jual-beli; dikatakan: saya telah menunjukkan anda pada sesuatu - dengan difathah dal-nya, dalalat(an), dan dilalat(an), serta didahmmah dalnya, dalul(an), atau dululat(an)— jika anda menunjukkan

${ }^{8}$ Muhammad bin Abi al-Fath, al-Muthalli', ed. Muhammad Basyir alAdlabi, al-Maktab al-Islami, Beirut, 1981, hlm. 279 
kepadanya, yaitu jika seorang pembeli menunjukkan kepadanya, maka orang itu adalah simsar (makelar) antara keduanya (pembeli dan penjual), dan juga disebut dalal.

Pada kasus MLM, seorang upline yang menempati posisi sebagai makelar, akan mendapatkan komisi atas pembelian yang dilakukan oleh bawahannya atau downline-nya, yang juga makelar. Ini menunjukkan bahwa upline tersebut mendapatkan komisi (prosentase) dari pembeli tidak lain downline yang sekaligus merupakan makelar juga. Praktek semacam ini tentunya adalah praktek yang bertentangan dengan syariat Islam.

Hal tersebut disebabkan perbuatan makelar dilakukan oleh seseorang terhadap sesama makelar yang lain. Karena itu, memakelari makelar atau samsarah 'ala samsarah tidak diperbolehkan. Sebab, kedudukan makelar adalah sebagai orang tengah. Atau orang yang mempertemukan (muslih) dua kepentingan yang berbeda; kepentingan penjual dan pembeli. Jika dia menjadi penengah orang tengah (mutawwith almutawwith), maka statusnya tidak lagi sebagai penengah. Dan gugurlah kedudukannya sebagai penengah, atau makelar. Inilah fakta makelar dan pemakelaran.

2. Dua Aqad dalam Satu Aqad

Imam Ahmad meriwayatkan sebuah hadits dari 'Abdullah bin Mas'ud ra, bahwasanya ia berkata:

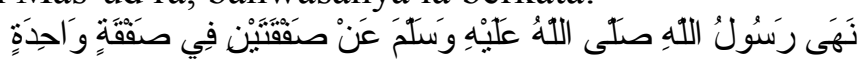

Artinya: "Rasulullah Saw melarang dua aqad dalam sebuah aqad jual beli. "(HR. Imam Ahmad).

Di dalam riwayat lain dituturkan, bahwasanya Abu Hurairah berkata:

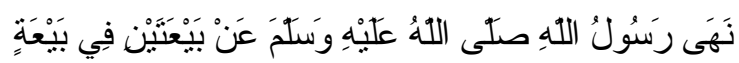

"Rasulullah Saw telah melarang dua aqad jual beli dalam satu aqad jual beli." (HR. at-Turmidzi). ${ }^{9}$

Konteks dari hadits di atas, yakni maksud dari bay'atayn fi bay'ah adalah melakukan dua akad dalam satu transaksi, akad

\footnotetext{
${ }^{9}$ As-Syawkani, Nayl al-Awthar, Dar al-Jil, Beirut, 1973, Jilid V, hlm.
} 248. 
yang pertama adalah akad jual beli budak, sedangkan yang kedua adalah akad jual-beli rumah. Namun, masing-masing dinyatakan sebagai ketentuan yang mengikat satu sama lain, sehingga terjadilah dua transaksi tersebut termasuk dalam satu aqad.

Jadi bila terjadi dua aqad dalam satu aqad ('aqdaain $f i$ 'aqd), atau "shafqatain bi shafqah" merupakan dua aqad yang terjadi dalam waktu bersamaan dan terkumpul menjadi satu dalam sebuah muamalah, maka Rasulullah SAW telah melarang kaum muslim melakukan dua aqad dalam sebuah transaksi.

Mengenai makelar di atas makelar atau dua aqad dalam satu aqad, banyak orang muslim yang mengklaim bahwa bisnis MLM itu halal dikarenakan adanya tali silaturrahmi di antara anggota atau member di perusahaan tersebut, atau adanya pembelajaran dalam berdagang, dan lain sebagainya. Namun untuk itu semua, tetaplah harus meninjau hal-hal yang lain. Maka dapat digunakan di sini kaidah :

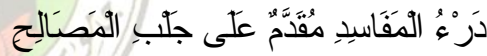
Artinya: "Menolak kerusakan itu didahulukan daripada mengambil kemaslahatan"

\section{Deskripsi Multi Level Muamalah (MLM) Jamaher}

Secara Etimologi Multi Level Marketing (MLM) berasal dari bahasa Inggris Multi berarti banyak sedangkan level berarti jenjang atau tingkat. Adapun marketing berarti pemasaran. Jadi dari kata tersebut dapat dipahami bahwa MLM adalah pemasaran yang berjenjang banyak. Disebut sebagai "Multi Level" karena merupakan suatu organisasi distributor yang melaksanakan penjualan yang berjenjang banyak atau bertingkat-tingkat.[3] Dalam pengertian "Marketing" sebenarnya tercakup arti menjual dan selain arti menjual, dalam marketing banyak aspek yang berkaitan dengannya antara lain ialah produk, harga, promosi, distribusi dan sebagainya. Jadi "Marketing" lebih luas maknanya dari menjual. Menjual merupakan bagian dari "Marketing" karena menjual hanyalah kegiatan transaksi penukaran barang dengan uang. [4] Andrias 
Harefa, dalam bukunya menyatakan bahwa inti dari bisnis Multi Level Marketing adalah Meet, Lear, and Multiply. Dalam bahasa Indonesia berarti bertemu, belajar, dan berlipat ganda.

Bisnis MLM atau juga dikenal dengan sebutan Network Marketing adalah suatu bentuk pendistribusian produk, baik berupa barang atau jasa.

Hafidz Abdurrahman dalam tulisannya menyatakan bahwa Multi level marketing secara harfiah adalah pemasaran yang dilakukan secara banyak tingkatan, terdapat istilah up line (tingkat atas) dan down line (tingkat bawah).[6] Up line dan down line merupakan suatu hubungan pada dua level yang berbeda, yakni ke atas dan ke bawah, dan jika seseorang disebut up line, maka ia mempunyai down line, baik satu maupun lebih.

Sedang MLM dalam kontek MLM jamaher.network adalah Multi Level Muamalah. Jika memang demikian.Dikatakan muamalah selain alasan karena bermula dari muamalah MLM Jamaher mengedapan maslahah. Jadi prinsionya ada dua kata dalam dunia ekonomi islam yang perlu dicermati yaitu istilah muamalah dan maslahah. Maka hal ini menjadi suatu yang baru dalam dunia network marketing yang menuntut serius untuk dikaji lebih dalam Apakah MLM ini benar-benar berprinsip syariah khususnya pada marketing plannya.

Sesunguhnya Jamaher.Network adalah komunitas Jamaher peduli kesehatan dan memberikan Peluang Bisnis. Untuk Anda siapa saja berkesempatan untuk menjalankan program web ini dengan MUDAH, AMAN, dan didukung sistem yang baik. Mengedapankan prinsip Maslahah. ${ }^{10}$ Jamaher sendiri sebenarnya merupakan singkatan dari Jamu Asli Herbal (Jamaher) yang terdiri dari 99 macam herbal nusantara terdiri dari empat komponen yaitu 1).Buah-buahan 2) batang batangan 2) daun-daunan dan 4)biji-bijian, yang disinyalir dapat membantu menyembuhkan berbagai penyakit. Seiring dengan perjelanan waktu dan pesatnya teknologi informasi, maka

${ }^{10}$ www.Jamaher.network 
jamaher membuat system network dengan nama www.jamaher.network dengan system mengedepankan nilainilai maslahah. Bahkan yang membuat

\section{Model Marketing Plan Jamaher.Network}

Untuk masuk dalam jaringan bisnis pemasaran Multi level Marketing, biasanya setiap orang harus menjadi member (anggota jaringan) terlebih dahulu, ada juga yang diistilahkan dengan sebutan distributor, kadangkala membership tersebut dilakukan dengan mengisi formulir pendaftaran keanggotaan dengan membayar sejumlah uang pendaftaran, disertai dengan pembelian produk tertentu agar anggota tersebut mempunyai point, dan kadang tanpa pembelian produk. Dalam hal ini, memperoleh point adalah sangat penting, karena suatu perusahaan MLM menjadikan point sebagai ukuran besar kecilnya bonus yang diberikan. Point tersebut bisa dihitung berdasarkan pembelian langsung, atau tidak langsung. Kegiatan pembelian langsung biasanya dilakukan oleh masing-masing anggota, sedangkan pembelian tidak langsung biasanya dilakukan oleh jaringan keanggotaannya. Dari sinilah, nantinya muncul istilah bonus jaringan. Karena dua kelebihan tersebut, bisnis MLM diminati banyak kalangan.

Untuk Bergabung dalam program JAMAHER NETWORK hanya Dengan Investasi Rp 250.000,- akan mendapatkan Fasilitas sebagai berikut: 1. Hak Usaha (2). Paket Produk JAMAHER (3). CRP (Custemer Referral Program) serta (4). Sistem Komisi dari program antara lain.

\section{Bonus Ta'aruf}

Tambahan Komisi Sponsoring / Ta'aruf sebesar 30.000 dari total downline Anda yang anda ajak untuk bergabung di Komunitas JAMAHER

2. Komisi Tawazun

Anda akan mendapatkan Komisi Tawazun

Keseimbangan sebesar Rp. 5.000,- Setiap terjadi 1 (satu) keseimbangan jumlah jaringan sebelah kiri dan kanan. Potensi 
Komisi Pasangan (Keseimbangan) Anda (Flush Out) 12 pasang ( 12 kiri : 12 kanan ) perusahaan memberlakukan sistem hangus terhadap hak usaha yang terjadi flushout.

Contoh: Jika di kiri berjumlah 3 dan kanan 3 ( bagaimanapun bentuknya), maka komisi pasangan Anda adalah:3 pasangan $\mathrm{X}$ Rp. $10.000,-=$ Rp. 30.000,- Selanjutnya bisa diilustasikan sebagai berikut:

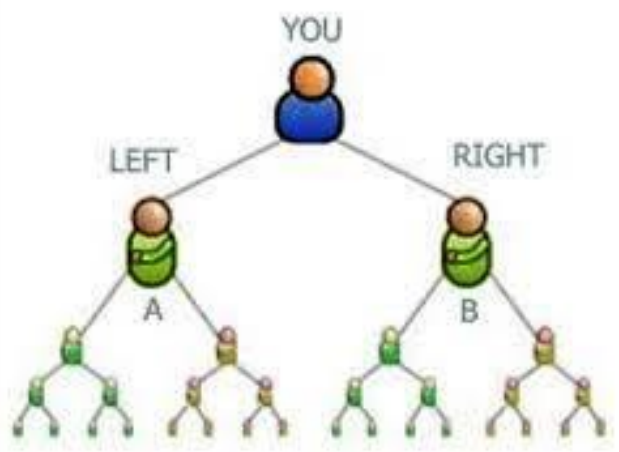

3. Komisi Mudharabah

Anda akan mendapatkan profit yang dibagikan setiap bulan,profit ini kami transfer ke statement komisi yang alokasi dari keuntungan setiap bulannya dari JAMAHER.NETWORK dibagikan kepada Seluruh Member Aktif. Profit ini didapat tanpa harus merekrut member atau mendapatkan downline, namun akan dibagikan secara merata ke setiap member yang bergabung di bisnis ini. Dengan adanya komisi ini member pasif pun akan tetap mendapatkan pendapatan setiap bulannya.

4. Bonus Balik Modal ( BEP)

Semua Mitra JAMAHER.NETWORK Berhak Mendapatkan Profit balik modal 1 kali selama menjadi member, komisi balik modal ini sebesar Rp. 250.000 dalam bentuk produk jamaher. Komisi balik modal ini akan dibagikan setiap bertambahnya 100 member baru. Contoh : Apabila bertambah member baru sebanyak 100 orang atau lebih, maka 10 orang member sesuai nomor urutan aktivasi akan mendapatkan komisi 
BEP ini, misalnya dari nomor urut aktivasi 1 sampai 10, dan apabila bertambah lagi 100 orang maka penerima BEP ini adalah nomor urut aktivasi 11 sampai 20, dan seterusnya.

5. Bonus Bisyarah

Komisi Prestasi ini akan didapat setiap bulannya kepada member yang memenuhi syarat, besarnya komisi ini adalah berdasarkan pendapatan bersih perusahaan.Berikut adalah Tabel komisi Prestasi yang kami terapkan:

Contoh kasus: Anda sudah mensponsori 100 orang member, maka berhak mendapatkan komisi prestasi ini dengan peringkat VIP sebesar 1\% dari total income perusahaan. Contoh perhitungan: Omzet yang didapat oleh perusahaan adalah Rp.50.000.000 maka anda berhak mendapatkan komisi peringkat sebesar Rp. 500.000 setiap bulannya.

6. Bonus Hibah

Komisi Lucky Member ini akan diberikan kepada 1 orang member setiap bulannya secara acak, setiap member hanya berhak mendapatkan 1 kali komisi ini sebesar Rp.250.000 Komisi Lucky ini akan keluar apabila ada penambahan jumlah member yang mendaftar di website ini minimal 250 orang perbulan.Perlu diingat bahwa kami memilih member penerima komisi ini berdasarkan prestasi yang kami pantau.

\section{Analisis Konsep Bisarah Jamaher Network Prespektif Ekonomi Islam}

Konsep pada jamaher seperti yang dijelaskan diatas, karena kepentingan kajian penulis sampaikan bahwa Komisi Prestasi ini akan didapat setiap bulannya kepada member yang memenuhi syarat, besarnya komisi ini adalah berdasarkan pendapatan bersih perusahaan. adalah Tabel komisi Prestasi yang ditetapkan dalam jamaher network. Misalnya pada kasus: Anda sudah mensponsori 100 orang member, maka berhak mendapatkan komisi prestasi ini dengan peringkat VIP sebesar $1 \%$ dari total income perusahaan. Contoh perhitungan: Omzet yang didapat oleh perusahaan adalah Rp.50.000.000 
maka anda berhak mendapatkan komisi peringkat sebesar Rp. 500.000 setiap bulannya.

Pada komisi tersebut akan selalu didapatkan pada member yang aktif atau tidak mengundurkan diri. Komisi bisyarah didapatkan setelah terpenuhi syarat yang ditentukan oleh jamaher network, member berhak mendapatkan karena prestasinya dalam menjalankan komisi ta'aruf.

Sedang konsep ekonomi islam bisyarah bisa diartikan sebagai hadiahMenurut istilah syar'i, maka hadiah ialah menyerahkan suatu benda kepada seorang tertentu agar terwujudnya hubungan baik dan mendapatkan pahala dari Allah tanpa adanya permintaan dan syarat.

Dan di sana ada sisi keumuman dan kekhususan di kalangan para ulama antara hibah, pemberian (athiyah) dan shadaqah. Dan poros definisi di antara tiga perkara ini adalah niat, maka shadaqah diberikan kepada seseorang yang membutuhkan dan dalam rangka mencari wajah Allah Ta'ala. Sedangkan hadiah diberikan kepada orang yang fakir dan orang kaya, dan diniatkan untuk meraih rasa cinta dan membalas budi atas hadiah yang diberikan (sebelumnya -pent). Dan terkadang pemberian hadiah itu juga bertujuan untuk mencari wajah Allah. Adapun hibah dan athiyah, tidak ada di antara keduanya perbedaan dan terkadang dimaksudkan untuk memuliakan orang yang diberikan hibah atau athiyah saja dikarenakan suatu keistimewaan atau sebab tertentu dari sebab-sebab yang ada.

Termasuk perkara yang tidak diragukan lagi, bahwa hadiah dalam kehidupan antar individu dan komunitas manusia memiliki pengaruh yang signifikan untuk terwujudnya ikatan dan hubungan sosial, ekonomi momen-momennya senantiasa terulang setiap hari di acara-acara keagamaan, kemasyarakatan, dan selainnya. Dengan hadiah, terwujudlah kesempurnaan untuk meraih kecintaan, kasih sayang, sirnanya kedengkian, dan terwujudnya kesatuan hati. Seiring perjalanan waktu konsep hadiah dewasa ini dapat berdampak negatif, jika salah memahami. Banyak koruptur ditangkap KPK akibat salah memaknai hibah dalam kontek islam. 
Dalam konsep Hadiah Jamaher Network merupakan bukti rasa cinta Jamaher Network kepada mitranya yng berprestasi tanpa memandang dari mana unsur member datang, jika komitmen semuanya memiliki peluang untuk mendpatkan komisi bisyarah, karena komisi bisyarah ini merupakan bentuk penghormatan dan pemuliaan kepada member yang prestasi. Landasan yang dapat dipakai pada komisi bisyarah ini terinspirasi sabda Rasulullah shallallahu 'alaihi wasallam menerima hadiah dan menganjurkan untuk saling memberi hadiah serta menganjurkan untuk menerimanya.Al Imam $\mathrm{Al}$ Bukhari telah meriwayatkan hadits di dalam Shahihnya (2585), dan hadits ini memiliki hadits-hadits pendukung yang lain. Dari 'Aisyah radhiyallahu 'anha, beliau berkata : "Rasulullah shallallahu "alaihi wasallam menerima hadiah dan membalasnya."

Dan di dalam Ash Shahihain (Shahih Al Bukhari dan Shahih Muslim) dari hadits Abu Hurairah radhiyallahu 'anhu, beliau berkata bahwa Rasulullah shallallahu 'alaihi wasallam apabila diberi makanan, beliau bertanya tentang makanan tersebut, "Apakah ini hadiah atau shadaqah?" Apabila dikatakan, "Shadaqah" maka beliau berkata kepada para shahabatnya, "Makanlah!" Sedangkan beliau tidak makan. Dan apabila dikatakan "Hadiah", beliau mengisyaratkan dengan tangannya (tanda penerimaan beliau -pent). Lalu beliau makan bersama mereka ${ }^{11}$.

Akhirnya menilik kajian tersebut diatas, bahwa kajian konsep biisyarah dalam jamaher network sebenarnya adalah hadiah dalam kajian islam..sehingga dalam prespektif ekonomi islam konsep bisyarah dapat ditemukan pada prinsip-prinsip ekonomi islam seperti menjaga keseimbangan ekonomi (prinsip tawazun) dan berpegang pada keadilan (prinsip adalah) sehingga dengan demikian tidak menutup kemungkinan visi maslahah akan tercapai.

\footnotetext{
${ }^{11}$ HR. Al Bukhari [2576] dan Muslim [1077
} 


\section{Kesimpulan}

Munculnya jamaher.network didunia MLM (Multi Level Marketing) yang menamakan MLM (multi level muamalah) adalah fenomena baru dalam dunia network. Sehingga perlu diperhatikan dan dipahami lebih lanjut secara universal. Penelitian tentang marketing plan khususnya pada konsep Bisyarah patut dipertimbangkan bagi networker dan akademisi khususnya bagi pengampu materi ekonomi islam dan entreprenuership karena pada konsep marketing bisyarah memungkin para member lebih semangat dalam menjalamkan bisnisnya. Dalam kontek ekonom islam konsep bisyarah dalam penelitian labih diasumsikan sebagai konsep hadiah dengan memakai prinsip adalah dan tawazun. Mudah-mudahan dapat menjadi salah satu pilihan alternatif berwirausaha. 


\section{DAFTAR PUSTAKA}

Dewan Syariah dalam MLM diambil dari http://www esyariah.com Diakses pada tanggal 27 Maret 2016

Fatwa DSN MUI Praktek Perbankan Syariah dalam http://pengusahamuslim.com/fatwa-dsn-mui-145 Diakses pada tanggal 27 Maret 2016

Harefa, Andreas. 1999, Multi Level Marketing, Jakarta: PT Gramedia Pustaka Utama,

Jurnal Dirosah Islamiyah, Menyoal Kehalalan Bisnis MLM, Jakarta, Vol.1 No.1 tahun 2003

Muhammad bin Abi al-Fath, al-Muthalli', ed. Muhammad Basyir al-Adlabi, al-Maktab al-Islami, Beirut, 1981

Rachmat Syafei, Ilmu Ushul Fiqh, Pustaka Setia, Bandung, tahun 1999

Syarifuddin, Amir. 2010, “Garis-Garis Besar Fiqih". Cet ke-3 Jakarta: Pranada Media Group

Yusuf, Tarmidzi. Strategi MLM Secara Cerdas dan Halal, Cet I, Jakarta: PT: gramedia, 2002

Sayyid Sabiq. Fiqih As-Sunnah, vol. III

As-Syawkani, Nayl al-Awthar, Dar al-Jil, Beirut, 1973, Jilid V 